\title{
Effect of Career Counseling on the Career Development of Secondary School Students in Kenya
}

\author{
Quinter Migunde \\ School of Education, Maseno University, PO box 333, Maseno, Kenya
}

\begin{abstract}
The purpose of the current study was to determine the effect of career counseling on students' career development in secondary schools in Kenya. The study sample consisted of 341 (158 males and 183 females) secondary school students from year one to year four of study. The students were surveyed on measures of career development. The study found that female students were more likely than male students to go for career counseling and that going for career counseling had no significant effect on students' career development. There was no significant difference between those who had gone for career counseling and those who had not for all the measured variables. There is therefore great need for the development of a comprehensive guidance and counseling policy to guide the implementation and service delivery of counseling programs.
\end{abstract}

Keywords: Career counseling, career developments, students, career barriers

DOI: $10.7176 / \mathrm{JEP} / 12-3-09$

Publication date: January $31^{\text {st }} 2021$

\section{Introduction}

Guidance and counseling services have become a necessity for all schools in our society today. According to Ngumbi (2012), guidance and counseling processes have been found to be the best approach to help children as well as their family members in dealing with frustrating issues. It is expected that an effective guidance and counseling program should have the necessary components such as educational and academic component, vocational component and personal or psychological component (Mungai, 2010).

Effective guidance and counseling services helps students in understanding themselves, developing personal decision making competencies, and being able to resolve personal problems (Gitonga, 2014). In addition, guidance and counseling program also help in providing occupational, educational and other information, which helps the students to formulate realistic educational and vocational plans (Wairagu, 2013).

Guidance and counseling in Kenyan schools was introduced in 1970 however it was formally implemented in 1971 (Wango, 2007). The guidance and counseling unit was charged with the responsibility of dealing with educational, vocational, and psychological guidance and counseling in schools (Ministry of Education, Science and Technology, 2005). According to Okech and Kimemia (2012) this initiative was not well supported hence implementation did not occur as was intended. In 1976 recommendations for guidance and counseling services in schools were made in a government policy document (Republic of Kenya, 1976). The policy document stated that guidance and counseling be taught in subjects such as religious education, social education and ethics to promote the growth of self-discipline among students in schools. Despite the government's emphasis of guidance and counseling in Kenyan schools, studies have consistently shown that there is a great variability on how counseling services are provided in schools and that guidance and counseling services have continually failed to meet the needs of students (Wambui \& Fisher, 2015).

The call for the establishment of guidance and counseling in Kenyan schools was renewed due to the rising state of unrest in secondary schools in the 1990s. In 2001 the government recommended that guidance and counseling departments be established in all schools (Republic of Kenya, 2001). In 2005 the government released a policy document detailing the government's plan for education. One of the areas identified as requiring government support was guidance and counseling. Among the issues identified that needed to be addressed through counseling were increasing numbers of HIV/AIDS orphans in schools, inadequate career opportunities, drug and substance abuse among students, and the many family problems that impact students' academic performance (Ministry of Education, Science and Technology, 2005).

1.1 Challenges facing guidance and counseling programs in schools

Despite the government's support for provision of guidance and counseling in schools, there are no comprehensive guidance programs in place yet (MOEST, 2005). Research has consistently shown that the guidance and counseling departments are faced with a number of challenges. The departments are run by teachers designated as counselors with very little or no training in counseling (Wambu \& Wickman, 2011). In addition to providing guidance and counseling these teachers still continue to perform duties as regular classroom teachers with a normal teaching load. This dual responsibility leaves the school counselor with very limited time to provide counseling services to students (Kamara, \& Mumiakha, 2011; Wambu \& Wickman, 2011). This in itself violates the ethics of dual relationship (Nyutu, 2007). As a result, it is difficult for the teacher to build a relationship with a student in a 
counseling session, while the same teacher is in charge of teaching and evaluating the student's academic achievement.

Research has shown that counseling services in most schools are conducted without any formal organizational structure (Migunde 2011). Most schools lack a specific counseling room and resources required for counseling. Wambui and Fisher (2015) noted that some schools in Kenya do not have a counseling office, and even where present; it lacks the necessary resources. In some schools, the school counselor shares the office with other teaching staff. This hinders effective service delivery. School counselors have also reported a lack of support from the school principal, school board members, teachers, parents, students and the community (Wambui \& Fisher, 2015).

\subsection{Career counseling}

Career counseling, also known as career guidance, is counseling designed to help with choosing, changing, or leaving a career. Career counseling was founded in the United States in the 19th century by Frank Parson. The main focus of career counseling was job placement. Parsons' career counseling model was grounded in simple logic and common sense and relied on the observing and interviewing skills of the counselor. He wrote that effective career placement requires knowledge of the special talents of the worker, the requirements of various occupations, and the relations between these sets of knowledge (Pope, 2000).

In Kenya, Career guidance is one of the main elements of guidance and counseling. In 1976, the Ministry of Education realized the importance of career counseling and came up with a handbook for career counselors (Republic of Kenya, 1979). The handbook was intended to provide information to school career counselors to enable them understand each school child as an individual in order to guide him/her to discover himself in terms of his intellectual abilities, to evaluate himself and work towards personal development and self-actualization, to choose a vocation for which he has the necessary potential and ability to master and succeed and finally to prepare

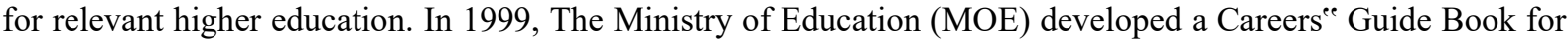
Schools which focuses on the need for students to be equipped with up-to-date information on the various dynamics on the modern world of work, the various careers that are still relevant, the type of professional and skills training required, as well as the various training opportunities available. The career guide book is intended to assist the learners in identifying their vocation or lifelong calling. In addition it is intended to help them assess their personal characteristics, strengths, weaknesses, dislikes and likes and relate them to selection of 8 subjects, appropriate post secondary courses and career options. The career book also gives an overview of each of the various broad careers and courses that one can train in. It also provides guidelines on where the courses are offered both locally and internationally (Orenge, 2011)

Despite this, students still lack proper career guidance in school. Every year about one third of students applying for university admission annually fail to get placement because of unsuitable subject combination and poor career choice. This means that teacher counselors are not well informed on careers available, career requirements and educational opportunities (Achungo, 2004). Due to the major discipline problems that have penetrated the school system, schools have concentrated more on psychological guidance and counseling to help students adjust socially to the school system and have neglected the important part of career guidance and counseling, and in some cases, students do not seek counseling services.

The knowledge that students acquires through career counseling is expected to help them remove confusion, anxiety, indecisiveness, and should empower them with information on clear career paths; relevant occupations in the context of their talents, academic abilities and market trends. However many secondary school students complete their studies without a clear understanding of the courses to enroll for upon joining institutions of higher learning (Njogu, Kibaara, \& Gichohi, 2019).

Research has consistently shown that there is little career counseling in many Kenyan schools, as a result students are unaware of the career options that exist (Wambui \& Fisher, 2015). Most career counselors / teachers still report lack career information as the main challenge is offering this service. Although schools have a career master, they lack necessary training (Nyutu, 2007). In most schools the career master's main role is to help students fill out university application forms. Very little information is provided with regard to available career options for the students. As a result, students select college courses with little knowledge of the work environments to which these courses will lead them (Nyutu, 2007). Without adequate training, a clear definition of role interventions, required resources and a well-structured career guidance and counseling program, Kenyan school counselors will continue to perform non counseling duties instead of addressing the many challenges students are currently facing.

\subsection{The current study}

The purpose of the current study is to determine the effect of career counseling on students' career development in secondary schools in Kenya. The current study will assess students' career development by assessing perceived barriers to career decision making, students' career locus of control, vocational identity, and career decision making self-efficacy.

Career decision making self efficacy (CDMSE) is the specific application of self efficacy theory in the domain 
of career studies. CDMSE is primarily based on Bandura's Social Cognitive Theory and Crites' Career Maturity Theory. Taylor and Betz define CDMSE as the extent which individuals believe that they can evaluate themselves, collect career information, select goals, make plans and solve problems relevant to career decision making (Wang, Zang \& Shao, 2010). The current study will determine whether there is any significant difference in the career decision making self efficacy of students who go for career counseling and those who do not.

Career locus of control refers to an individual's belief that their career outcomes are dependent on internal or external factors. There are two types of locus of control: internal and external locus of control. According to Miller and Shevlin (2007), internal locus of control can be defined as the expectancies held by adolescents related to how projected career outcomes are perceived to be within their personal control through behaviour and decision making whereas an external career locus of control refers to expectancies relating to how career related outcomes are contingent on factors outside of their personal sphere of behaviour such as luck, fate, chance and powerful others. The current study will determine whether there is any significant difference in the career locus of control of students who go for career counseling and those who do not.

Tuner and Lapan (2005) defined vocational identity (VI) as the integration and crystallization of an individual's energy, aptitudes and opportunities into a consistent sense of uniqueness of himself/herself and fit into the vocational world. Vocational identity formation has been considered a central developmental task that adolescents have to cope with (Koumoundourou, Kounenou, \& Siavara, 2012). Individuals with concrete vocational identity are considered as having more ease in making career decisions (Scott \& Ciani, 2008). This is because they are considered as having a clear sense of their interests, personality characteristics and stable career related goals. They are also considered as having greater ease and confidence in career decision making (Gushue et al, 2006). The current study will determine whether there is any significant difference in the vocational identity of students who go for career counseling and those who do not.

Career barriers have been defined as any factor that block the achievement of career goals (Creed, Patton and Bartum, 2004). Career barriers have been viewed as either internal such as lack of confidence or external such as lack of access to education. The current study will determine whether there is any significant difference in the perceived barriers to career decision making of students who go for career counseling and those who do not.

Career indecision has been defined as the inability to make decisions about the career one wishes to pursue (Guay, Senecal, Gauthier, \& Fernet, 2003). It is considered a normal response when young people are required to make career related decisions. It may occur at any moment when individuals are contemplating on their careers but especially during transition points such as when choosing school subjects or university program (Creed, Patton and Prideaux 2006). The current study will determine whether there is any significant difference in the career decision making status of students who go for career counseling and those who do not.

\section{Methodology}

The current study used correlation and cross-sectional research designs. The study was conducted in Kisumu County, Kenya with a sample of 341 secondary school students. The age of respondents ranged from 13 to 21 . The mean age of the respondents was 16 . The sample consisted of 158 male and 183 female respondents.

\subsection{Data Collection Instruments}

Questionnaire was used to gather information about students' opinion on career decision making and the various variables that affect their career decision making. The following instruments were used to gather information from the respondents: -

Demographic questionnaire was used to gather basic information about the students such as age and gender.

The Career Decision Making Self-Efficacy Scale (CDSES-SF; Betz, Klein, \& Taylor, 1996) was used to assess the career decision making self-efficacy of students in the study. This instrument measures an individual's degree of belief that he/she can successfully complete tasks necessary for career decisions. It consists of 25 items and has five subscales which measure self-appraisal, occupational information, goal selection, career planning and problem solving. Nilsson, Schmidt, and Meek (2002) reported reliability coefficients of .83 .

The Career Locus of control Scale (CLCS; Millar \& Shevlin, 2007) was used to measure career locus of control of the respondents. The scale consists of 20 items measuring both internal and external locus of control. Santos and Ferreira (2012) reported an internal consistency coefficient of .69.

The Career Decision Scale (CDS; Osipow et al, 1976) was used to measure career indecision of the students. The scale contains 19 items which consists of two subscales. 16 items form the indecision subscale while 2 items measure the degree of certainty felt in having made a career decision. Osipow et al 1996) reported a two week test retest reliability of .90 and .81. Wang et al (2006) reported a Cronbach's alpha of .91. Patton and Creed (2007) reported .89 .The reliability coefficient for the current study was .74.

Vocational identity of the students was measured using the Vocational Identity Scale (VIS; Holland, Daiger \& Power, 1980) which consists of 18 items. This scale measures the possession of clear and stable picture of one' goals and interest. Sample items include: 'I am uncertain about what occupations I would enjoy' and 'making up 
my mind about a career has been long and difficult'. Holland, Daiger \& Power (1980) reported internal consistency reliability ranging from .86 to.89. Wang et al reported .85 and Koumoundourou reported Cronbach's alpha of .75. The reliability coefficient for the current study was .71 .

Career Barriers was assessed using a modified version of the perceived Barriers scale (PBS; Howell et al 1977). The scale consists of 9 items. Patton and Creed (2007) reported a coefficient alpha of .81 for the scale. The reliability coefficient for the current study was .73.

The instruments were administered to the 40 students on one occasion. To estimate reliability, the Cronbach's alpha test was run using the reliability command in SPSS for each of the instruments. This was done to estimates how well items that reflect the same construct yield similar results. The coefficient level was set at 0.70 . Results for the reliability of the instruments used were as follows: - Career Decision Making Self-Efficacy Scale .82, Career Locus of Control Scale .77, The Career Decision Scale .74, Vocational Identity Scale .71 and Career Barriers .68.

\subsection{Data Collection Procedures}

Before undertaking the study, the researcher sort ethical approval from Maseno University Ethics Review Committee (MUERC) through the School of Graduate Studies (SGS). The researcher also visited the County Director of Education and the District Directors of education for a courtesy call and informed them of study area. The researcher then visited the sampled schools for introduction and familiarity with the schools and principals. The visit was also meant to seek permission from the principals and to agree on the date to conduct the study. A second visitation was made to collect data.

Prior to administering the instrument, the participants were briefed on the nature of the research. The participants were advised that their responses would be anonymous and would be used for the purpose of research only. Participation was voluntary; those who agreed to participate in the research were given consent forms to append their signatures. Participants were then issued with the questionnaire which they filled. Participants who were through with the exercise gave back the filled questionnaire to the researcher.

\subsection{Methods of Data Analysis}

Scores were summed up for each scale to get the total score for each respondent on variables under study. Frequencies, percentages, chi square and t-test were used to analyse the data.

\section{Results}

Descriptive statistics were used to determine the percentage of students who have gone for career counseling. Out of 341 respondents 249 had gone for career counseling while 92 had not gone for career counseling. Figure 1 shows that more females (146) go for career counseling than males (103). The results are presented in Fig 1.

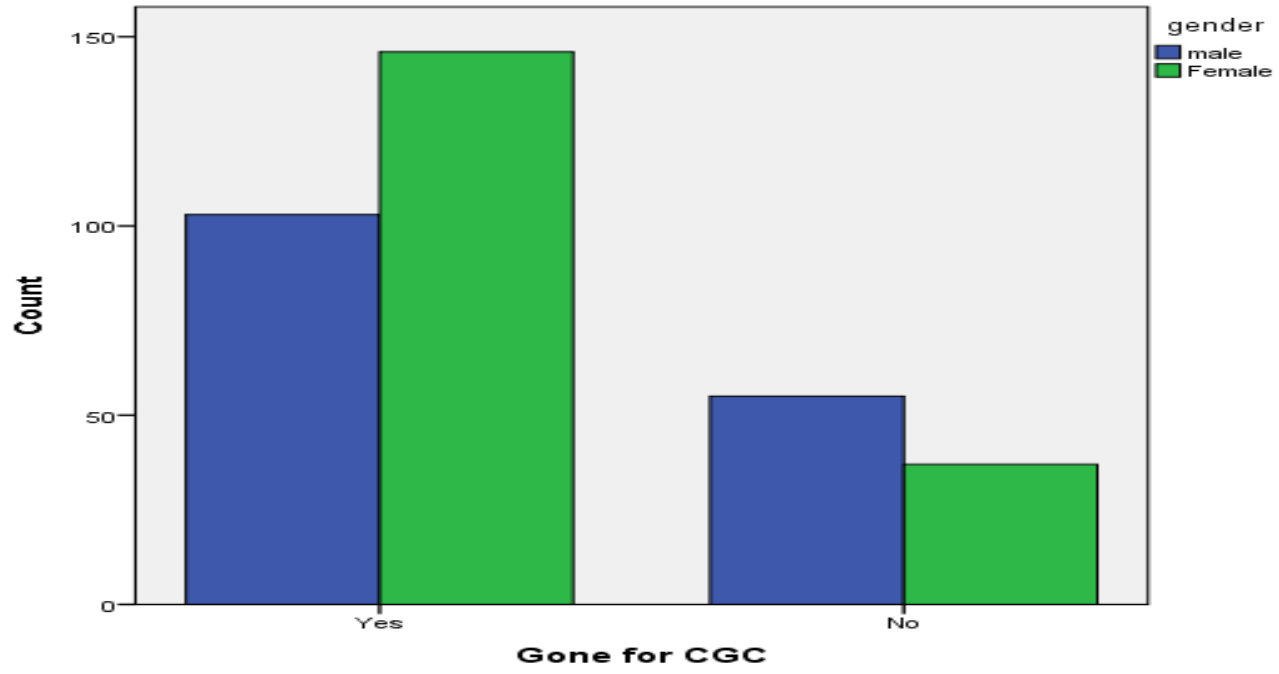

Fig 1: Number of Students who have gone for Career Counseling

A chi-square test of independence was performed to examine the relationship between gender and going for career counseling. The relationship between the two variables was significant $\chi^{2}(1, N=341)=9.16, p=.003$. Female students were more likely than male adolescents to go for career counseling. The results are presented on table 1 . 
Table 1: Crosstabs Table for Relation between Gender and Going for Career Counseling

\begin{tabular}{|c|c|c|c|c|c|}
\hline & Value & df & $\begin{array}{l}\text { Asymp. Sig. (2- } \\
\text { sided) }\end{array}$ & $\begin{array}{l}\text { Exact Sig. (2- } \\
\text { sided) }\end{array}$ & $\begin{array}{l}\text { Exact Sig. (1- } \\
\text { sided) }\end{array}$ \\
\hline Pearson Chi-Square & $9.164^{\mathrm{a}}$ & 1 & .002 & \multirow{7}{*}{.003} & \multirow{7}{*}{.002} \\
\hline Continuity Correction & 8.438 & 1 & .004 & & \\
\hline Likelihood Ratio & 9.173 & 1 & .002 & & \\
\hline Fisher's Exact Test & & & & & \\
\hline Linear-by-Linear & 9.137 & 1 & .003 & & \\
\hline Association & & & & & \\
\hline $\mathrm{N}$ of Valid Cases & 341 & & & & \\
\hline
\end{tabular}

To establish the effect of career counseling on students' career development, Independent sample t-tests were conducted to compare scores on career variables for students who had attended career counseling and those who had not attended career counseling, the results are presented on table 2. For perceived barriers in career decision making there was no significant difference for those who had gone for career counseling $(M=22.12, S D=4.69)$ and those who had not attended career counseling $(M=22.67, S D=4.71) ; t(339)=-.958, p=.34$. These results suggest that going for career counseling does not have a significant effect on the nature of barriers students experience in relation to making career decisions.

Table 2: Independent sample t-tests comparing scores on career variables for students who have attended career counseling and those who have not attended career counseling

\begin{tabular}{|c|c|c|c|c|c|c|c|c|}
\hline & $\begin{array}{l}\text { Gone for } \\
\text { CC }\end{array}$ & $\mathbf{N}$ & Mean & SD & $\mathbf{t}$ & Df & Sig. & MD \\
\hline \multirow[t]{2}{*}{ Perceived Barriers } & Yes & 249 & 22.12 & 4.69 & -.958 & 339 & .339 & -.55 \\
\hline & No & 92 & 22.67 & 4.71 & & & & \\
\hline \multirow{2}{*}{ External Locus of Control } & Yes & 249 & 35.73 & 10.70 & -.651 & 339 & .516 & -.84 \\
\hline & No & 92 & 36.57 & 10.46 & & & & \\
\hline \multirow[t]{2}{*}{ Internal Locus of Control } & Yes & 249 & 21.25 & 3.64 & 1.040 & 339 & .299 & .47 \\
\hline & No & 92 & 20.77 & 3.96 & & & & \\
\hline \multirow[t]{2}{*}{ Vocational Identity } & Yes & 249 & 28.82 & 4.12 & 1.24 & 339 & .215 & .48 \\
\hline & No & 92 & 28.22 & 3.90 & & & & \\
\hline \multirow{4}{*}{$\begin{array}{l}\text { Career Decision Making Self } \\
\text { Efficacy } \\
\text { Career Indecision }\end{array}$} & Yes & 249 & 92.15 & 15.36 & 1.302 & 339 & .194 & 2.37 \\
\hline & No & 92 & 89.79 & 13.55 & & & & \\
\hline & Yes & 249 & 35.51 & 7.69 & -.853 & 339 & .394 & -.81 \\
\hline & No & 92 & 36.31 & 7.92 & & & & \\
\hline
\end{tabular}

Locus of control was divided into two subscales i.e. Internal and External Career Locus of Control. For External Locus of Control there was no significant difference for those who had gone for career counseling ( $M$ $=35.73, S D=10.70)$ and those who had not attended career counseling $(M=36.57, S D=10.46) ; t(339)=-.651$, $p=.52$. For Internal Locus of Control there was also no significant difference for those who had gone for career counseling $(M=21.25, S D=3.64)$ and those who had not attended career counseling $(M=20.77, S D=3.96) ; t$ $(339)=1.040, p=.30$. These results suggest that going for career counseling does not have a significant effect on students' belief that their career outcomes are dependent on internal or external factors

For Vocational Identity there was no significant difference for those who had gone for career counseling ( $M$ $=28.82, S D=4.12)$ and those who had not attended career counseling $(M=28.22, S D=28.22) ; t(339)=1.24, p$ $=.22$. These results suggest that going for career counseling does not have a significant effect on students' development of stable interests and goals.

For Career Decision Making Self Efficacy there was no significant difference for those who had gone for career counseling $(M=92.15, S D=15.36)$ and those who had not attended career counseling $(M=89.79, S D=$ $13.55) ; t(339)=1.302, p=.19$. These results suggest that going for career counseling does not have an effect on the respondent's confidence in their ability to make career related decisions.

For Career Indecision there was no significant difference for those who had gone for career counseling $(M=$ $35.51, S D=7.69)$ and those who had not attended career counseling $(M=36.31, S D=7.92) ; t(339)=-.853, p$ $=.39$. These results suggest that going for career counseling does not have an effect on the respondent's inability to make career decisions.

The primary goal of career counseling is to make it possible for an individual to see and explore his/her unlimited endowed options. According to Amoah et al (2015) career counselors are expected to offer students with comprehensive career programs and career related information aimed at making students plan, make decisions and finally choose the right vocation. When this is done, students will be able to overcome career related barriers, develop confidence in making career related decisions, have clear goals and make appropriate decisions. 


\section{Conclusion}

Based on their above findings it is important to note that female students were more likely than male students to go for career counseling. Going for career counseling was however not very effective in students' career development. There was no significant difference between those who had gone for career counseling and those who had not for all the measured variables. This implies that the kind of career counseling students undergo does not provide them with comprehensive career related information

\section{Recommendations}

There is great need for the development of a comprehensive guidance and counseling policy to guide the implementation and service delivery of counseling programs. To be effective, school counselors will need support from all the stakeholders. Counseling departments also need to be equipped with necessary resources to enable career counselors provide appropriate career guidance and counseling to students.

\section{References}

Achungo, E. P. (2004). Students access to career guidance and counseling in secondary schools in Kakamega District Western Province. Unpublished Thesis, Nairobi University.

Amoah, S. A., Kwofie, I., \& Kwofie, F. A. (2015). The School Counselor and Students' Career Choice in High School: The Assessor's perspective in a Ghanaian Case. Journal of Education and Practice 6(23), 57-65

Betz, N. E., Klein, K. L., \& Taylor, K. M. (1996). Evaluation of a short form of the Career Decision-Making SelfEfficacy Scale. Journal of Career Assessment, 4(1), 47-57. https://doi.org/10.1177/106907279600400103

Constantine, M. G., Wallace, B. C., \& Kindaichi, M. M. (2005).Examining contextual factors in the career decision status of African American adolescents. Journal of Career Assessment, 13, 307-319.

Creed, P. A., Patton, W., \& Bartrum, D. (2004).Internal and external barriers, cognitive style and the career development variables of focus and indecision. Journal of Career Development, 30, 277-294.

Creed, P. A., Patton, W., \& Prideaux, L.A. (2007).Predicting change over time in career planning and career exploration for high school students. Journal of Adolescence, 30, 377-392.

Creed, P., Patton, W., \& Prideaux, L. (2006).Causal relationship between career indecision and career decisionmaking self-efficacy. Journal of Career Development, 33, 47-65.

Gitonga, G., (2014). Institutional Factors Influencing Provision of Guidance and Counseling in Secondary Schools in Starehe District, Nairobi County. Unpublished Masters Project, University of Nairobi

Government of Kenya (2005b). Kisumu District Strategic Plan (2005-2010) for the implementation of the national population policy for sustainable development. Nairobi: National coordination agency for population and development.

Government of Kenya (2006b).Education Sector Report. Nairobi: Government Printer.

Government of Kenya. (2001). The children's act, 2001. Kenya Gazette supplement No. 95, Acts No 8. Nairobi, Kenya:

Guay, F., Senecal, C., Gauthier, L., \& Fernet, C. (2003).Predicting career indecision: A self-determination theory perspective. Doi: 10.1037/0022-0167.50.2.165.

Gushue, G. V., \& Whiston, M. L. (2006). The relationship among support, ethnic identity, career decision making self-efficacy and outcome expectations in African American high school students: applying social cognitive career theory. Journal of Career Development 33, 112-124.

Gushue. G. V., Clarke C. P., Pantzer, K. M., \& Scanlan, K. R. L. (2006). Self-efficacy, perceptions of barriers, vocational identity and the career exploration behaviour of Latino high school students. Career Development Quarterly, 54, 307-317.

Holland, J. L., Daiger, D. C., \& Power, P. G. (1980). My vocational situation: Description of an experimental diagnostic form for the selection of vocational assistance. Palo Alto, CA: Consulting Psychologists Press.

Howell, F. M., Frese, W., \& Soille, C. R. (1977). Ginzenberg's theory of occupational choice: a re-analysis of increasing realism. Journal of Vocational behaviour 11,332-346.

Koumoundourou, G. A., Kounenous, K., \& Siavara, E. (2012).Core self-evaluation, career decision making selfefficacy and vocational identity among Greek adolescents. Journal of Career Development 39, 269-269.

Migunde, Q., Agak, J., \& Odiwuor, W. (2011).Career aspirations and career development barriers of adolescents in Kisumu municipality, Kenya. Journal of Emerging Trends in Educational Research and Policy Studies, 2, $320-324$

Millar, R., \& Shevlin, M. (2007). The development and factor structure of a career locus of control scale for use with school pupils. Journal of Career Development, 33, 224-249.

Ministry of Education Science and Technology. (2005). Kenya education sector support program 2005-2010. Retrieved from http://planipolis.iiep.unesco.org/upload/Kenya/Kenya\%20KESSP\%20FINAL\%202005.pdf

Mumiukha, K. (2011). Challenges facing secondary schools' guidance counselors in Kenya. Journal of Education and Human Resources. Retrieved from http://journal.egerton.ac.ke/ 
Mungai, C., (2010). Factors Affecting the Effectiveness of Guidance and Counseling Services in Kenyan Secondary Schools; A Case Study of Thika Town of Ruiru Educational Zone. Unpublished Master's Thesis, Kenyatta University

Ngumbi, E., (2012). Challenges Facing Teachers in Implementation Guidance and Counseling Services in Public Secondary Schools in Kikuyu Division in Kiambu District, Kenya. Unpublished Masters Project, University of Nairobi

Nilsson, J. E., Schmidt, C. K., \& Meek, W. D. (2002). Reliability generalization: An examination of the Career Decision-Making Self-Efficacy Scale. Educational and Psychological Measurement, 62(4), 647658. https://doi.org/10.1177/0013164402062004007

Njogu, w., Kibaara, d. T., \&gichohi, d. P. (2019). How career guidance services affect career choice among public secondary school students in Meru county, Kenya. African journal of emerging issues, 1(8), 1 - 13.

Nyutu, P. N. (2007). The development of the student counseling needs scale. Retrieved from ProQuest Dissertations and Theses database. (UMI No. 3351653).

Obura, C. A. (2007). Perceptions of career aspirations of secondary school students in Kisumu Municipality. (Unpublished Masters Thesis).Maseno University.

Omondi, A. N. (2007). Career guidance in secondary schools in Kisumu district, Kenya: Implications for the curriculum. (Unpublished Master's Thesis).Maseno University.

Orenge, E., (2011). The Status of Career Guidance and Counseling Services for Students in Nairobi Province. Unpublished Masters Project, Kenyatta University.

Osipow, S. H., Carney, C. G., Winer, J. L., Yanico, B. J., \& Koschier, M. (1976). The Career Decision Scale (3rd ed., rev.). Columbus, OH: Marathon Consulting \& Press.

Patton, W. A., \& Creed, P. (2007).The relationship between career variables and occupational aspirations for Australian high school adolescents. Journal of Career Development, 34(2) 127-148.

Pope, M. (2000). A brief history of career counseling in the United States. Career Development Quarterly, 48, 194-211

Republic of Kenya. (1976). Report of the national committee on educational objectives and policies. Nairobi, Kenya: Government Printers.

Republic of Kenya. (2001). Report of the task force on students' discipline and unrest in secondary schools. Nairobi, Kenya: Jomo Kenyatta Foundations.

Santos, P. J., \& Ferreira, A. J. (2012). Career decision status among Portuguese secondary school students: A cluster analytic approach. Journal of Career Assessment, 20, 166-181.

Scott, P.A., \& Ciani, K. D. (2008).Effect of undergraduate career class on men's and Women's career decision making self-efficacy and vocational identity. Journal of Career Development, 34, 263-285.

Turner, S.L, \&Lapan, R. T. (2005). Evaluation of an intervention to increase non-traditional career interests and career related self-efficacy among middle school adolescents. Journal of vocational behaviour, 66, 516-531.

Wairagu, M., (2013) Institutional management practices for enhanced comprehensive guidance and counseling services in public secondary schools in Kahuro district, Murang'a County, Kenya. Kenyatta University thesis

Wambu, G. W., \& Fisher, T. A. (2015). School guidance and counselling in Kenya: Historical development, current status and future projects. Journal of Education and Practice 6, 93-102.

Wambu, G. W., \& Wickman, S. A. (2011). Advocacy for Kenyan school counselors and the counseling profession. Journal of Counseling in Illinois, 2, 34-42.

Wambui, G. W., \& Fisher, T. A. (2015). School Guidance and Counseling in Kenya: Historical Development, Current Status, and Future Prospects. Journal of Education 6 (11)94 - 102

Wang, J., Zhang, D., \& Shao, J. (2010).Group training on the improvement of college students' career decision making self-efficacy. Health 2, $551-556$.

Wango, G. \& Mungai E. (2007). Counseling in the School: A Handbook for the Teacher Nairobi: Phonex 